\title{
Cardiovascular Activity of the Chemical Constituents of Essential Oils
}

\author{
Tadeu Uggere de Andrade ${ }^{1}$, Girlandia Alexandre Brasil ${ }^{1}$, Denise Coutinho Endringer ${ }^{1}$, \\ Flávio Rogério da Nóbrega ${ }^{2}$ and Damião Pergentino de Sousa ${ }^{2, *}$ \\ 1 Departamento de Farmácia, Universidade de Vila Velha, Vila Velha ES 29102-770, Brazil; \\ tadeu.uggere@uvv.br (T.U.d.A.); girlandiabrasil@hotmail.com (G.A.B.); denise.endringer@uvv.br (D.C.E.) \\ 2 Departamento de Ciências Farmacêuticas, Universidade Federal da Paraíba, João Pessoa PB 58051-970, \\ Brazil; frnobrega@hotmail.com \\ * Correspondence: damiao_desousa@yahoo.com.br; Tel.: +51-83-3209-8417
}

Received: 20 August 2017; Accepted: 8 September 2017; Published: 17 September 2017

\begin{abstract}
Cardiovascular diseases are a leading cause of death in developed and developing countries and decrease the quality of life, which has enormous social and economic consequences for the population. Recent studies on essential oils have attracted attention and encouraged continued research of this group of natural products because of their effects on the cardiovascular system. The pharmacological data indicate a therapeutic potential for essential oils for use in the treatment of cardiovascular diseases. Therefore, this review reports the current studies of essential oils chemical constituents with cardiovascular activity, including a description of their mechanisms of action.
\end{abstract}

Keywords: monoterpene; sesquiterpene; phenylpropanoid; natural products; spasmolytic; smooth muscle; hypertension; heart; vasorelaxation

\section{Introduction}

Non-communicable diseases (NCD) are the leading causes of death worldwide and are responsible for approximately $68 \%$ of all global deaths in 2012. The main causes for NCD are cardiovascular diseases (CVD), which account for $46.2 \%$ of NCD-related deaths. CVD are responsible for 17.3 million deaths per year, a number that is expected to grow to more than 23.6 million by 2030 [1]. Although a wide range of pharmacological agents are available for the treatment of CVD, the control and prevention of these diseases continues to be a challenge. The cost of treatment continues to increase, which makes CVD even more expensive and impactful to the budget of public health systems around the world [2]. Therefore, new tools for the treatment of CVD are necessary for a cost that is reasonable for health systems. Among the sources of drug candidates available for the treatment of CVD, natural products have been reported to have a potential role in the therapeutic effects of such diseases [3]. The evaluation of the chemical constituents of plants has enriched the pharmacological arsenal used in the treatment of diseases, and it has helped to understand their pathological mechanisms [4].

It is well established that oxidative stress influences the pathogenesis of heart diseases, such as hypertension, atrial fibrillation, and atherosclerosis, and studies have demonstrated the implication of this stress in these diseases [5]. There is substantial epidemiological and experimental evidence that antioxidants in the diet can be preventive for heart disease [5]. The failure of antioxidants found in foods, such as vitamins $C$ and $E$, to prevent these disorders has led to the exploration of the ROS-suppressive effects of drugs used in the treatment of cardiovascular disease [6,7]. Moreover, many natural products have antioxidant and various other pharmacological properties [8]. Some of their actions on oxidative stress are associated with pharmacological effects [9-12]. Natural products with antioxidant and/or vasorelaxant effects have been shown to positively affect many cardiovascular conditions $[13,14]$ once the redox status or the vascular function has worsened and is 
implicated in the pathogenesis of the CVD $[15,16]$. Several studies have shown that the antioxidant properties of natural products have potential uses in the prevention and treatment of some heart diseases $[5,17,18]$. One of the natural products that have piqued the current interest of researchers are essential oils [19]. This group of natural products consists of aromatic and lipophilic substances that are found in many medicinal plants. At present, over 3000 essential oils are known, of which 300 are commercially important, especially in the pharmaceutical, food, sanitary, cosmetic, and perfume industries [20]. Recent reviews have shown the therapeutic potential of this group in multiple areas, including: analgesics [21,22], anticonvulsants [23], anti-inflammatories [24-26], anticancer agents [27-29], anxiolytics [30], and antiulcer agents [31]. Essential oils and their constituents have also been shown to be promising substances in the development of therapeutic agents applied to cardiovascular diseases. These findings not only support the traditional use of aromatic plants and their essential oils but also highlight new cardiovascular functions of these natural products that were previously unknown [32]. Therefore, the purpose of this review was to conduct a systematic investigation of essential oil studies in experimental models related to cardiovascular activity.

The search was conducted in the scientific database PubMed, focusing on works published during the last five years (January 2011 to December 2015). The data were selected using the following terms: "essential oils", "monoterpene", and "cardiovascular".

\section{Results and Discussion}

\subsection{Thymoquinone}

Thymoquinone is the main monoterpene of the volatile oil obtained from the seeds of Nigella sativa L. (Ranunculaceae). It exhibits several pharmacological activities, such as acting as an anti-inflammatory [26], antitumor agent [29] and as an analgesic [21]. Antioxidant and vascular relaxant effects of thymoquinone (TQ) have been documented in different experimental models of cardiovascular diseases. Aydin et al. [33] observed that treatment with TQ was associated with the reduction in the oxidative stress systemically measured after abdominal aorta ischemia or reperfusion injury in rats. This reduction in oxidative stress was associated with less severe lesions in the hearts of rats that received TQ intraperitoneally. The antioxidant mechanism of TQ involves reactive oxygen species (ROS), redox-related enzymes, and cytokine profiles. Nemmar et al. [34] observed that TQ improved the superoxide dismutase activity and reduced the interleucin- 6 content in mice, which prevented cardiovascular side effects induced by a pollutant. TQ induced a dose-dependent reduction in plasmatic lactate dehydrogenase (LDH), thiobarbituric acid reactive substances (TBARS), and glutathione reductase (GR), whereas SOD activity in the plasma and the myocardial reduced or oxidized glutathione ratio (GSH/GSSG) were increased in rats with an isoproterenol-induced myocardial infarction that were then treated with TQ. These actions protect the heart from the injury resulting from isoproterenol [35]. Oxidative stress is also implicated in vascular dysfunction by blunting both nitric oxide (NO)- and endothelium-derived hyperpolarizing factor (EDHF)-mediated relaxation in the arteries of ageing animals. TQ could reverse the age-related down-regulation of the endothelial NO synthase (eNOS) and increased the vascular formation of ROS in the mesenteric artery. In addition to the effects on oxidative stress, TQ also affects components of the renin-angiotensin aldosterone system (RAS) and increases the expression of the small and intermediate conductance $\mathrm{Ca}^{2+}$-activated $\mathrm{K}^{+}$channel (SKCa and IKCa, respectively), resulting in the incremental NO- and EDFH-induced mesenteric relaxation. These actions determined the improvement of endothelial function in ageing animals after 14 days of TQ treatment [36]. In addition, Ghayur et al. [37] observed that the relaxant effect of TQ in the aortas of rats should also involve the blockade of voltage-operated $\mathrm{Ca}^{2+}$ channels (VOCC). Taken together, these studies indicate that TQ has broad actions on the cardiovascular system, including the redox system, ion channels, the RAS system, endothelial-related relaxant agents, and cytokines. These actions result in antioxidant and vascular relaxant effects which work to protect the cardiovascular system. 


\subsection{Cinnamaldehyde}

This aromatic aldehyde is an active constituent isolated from the stem bark of cinnamon trees such as Cinnamomum cassia Presl. and others plants [38]. El-Bassossy et al. [39] showed that cinnamaldehyde normalized the vascular contractility and prevented the development of hypertension in insulin deficient or resistant animals, also prevented the hyper-responsiveness to vasoconstrictor agents (Phenylephrine or $\mathrm{KCl}$ ) and the hypo-responsiveness to vasodilatory agents (Ach) in the aortic rings. In insulin-deficient animals, cinnamaldehyde prevented the inhibition of NO release, while in insulin resistant rats, cinnamaldehyde prevented the elevated influx of $\mathrm{Ca}^{2+}$. Through an antioxidant action and the preservation of the NO levels, cinnamaldehyde protected the endothelium relaxation in the aortic rings of hyperglycemic mice. This antioxidant mechanism involved the up-regulation of the endogenous antioxidant enzyme NF-E2-related factor 2 (Nrf2) [40], which is known to regulate the generation of ROS [41]. Additionally, Raffai et al. [42] demonstrated that cinnamaldehyde also induced vascular relaxation in porcine coronary arteries through an endothelium-independent mechanism by inhibiting $\mathrm{Ca}^{2+}$ sensitivity and $\mathrm{Ca}^{2+}$ influx. When carried in micelles, cinnamaldehyde was also able to induce endothelium-dependent vascular relaxation by $\mathrm{NO}$ - and $\mathrm{H}_{2} \mathrm{O}_{2}$-dependent means. This was also demonstrated by Xue et al. [43], who showed that this relaxant effect of cinnamaldehyde was likely mediated by changes in calcium influx or in its release from intracellular stores. Additionally, Alvarez-Collazo et al. [44] studied the mechanism of action of this compound and showed that CA promoted relaxation in vascular smooth muscle cells (VSMC) and ventricular cardiac myocytes (VCM), at least in part by inhibition of the L-Type $\mathrm{Ca}^{2+}$ channel. Additionally, these studies do not exclude subtype 1 of the Transient Receptor Potential Ankyrin (TRPA1).

Song et al. [14] evaluated the cardioprotective properties of cinnamaldehyde against the ischemic injury precipitated by isoproterenol. The pre-treatment for 14 days with cinnamaldehyde resulted in decreased cardiac injury (hypertrophy and histological changes), decreased pro-inflammatory cytokines (TNF- $\alpha$ and IL-6), increased serum NO and SOD levels on the heart, and reduced ST segments generated by myocardial ischemia. Together, these results show that cinnamaldehyde has cardioprotective effects that can be attributed to antioxidant and anti-inflammatory proprieties.

\subsection{Cinnamic Acid}

This compound is an aromatic carboxylic acid with carbonic structure $\mathrm{C} 6-\mathrm{C} 3$ appearing naturally in the plant kingdom. In addition, cinnamic acids are formed in the biosynthetic pathway leading to various natural product classes, such as phenylpropanoids, flavonoids, coumarins, lignans, anthocyanins, and tannins [45]. In vitro analysis of vasorelaxant proprieties of cinnamic acid (CA) was conducted by Kang et al. [46] who used the thoracic aortas of rats. They showed that CA promoted vasorelaxation in a dose- and endothelium-dependent manner, once both NO inhibition by L-NAME and endothelium removing reduced its relaxant effect. The increases of e-NOS and pe-NOS after CA incubation on the cell cultures of human endothelium strongly reinforced this hypothesis. Additionally, the participation of Protein Kinase G (PKG) as a mediator was demonstrated due to the increase of cGMP observed after the incubation of cells with CA. Together, these results demonstrate that CA promotes vasorelaxant effects by changing the endothelium-NO release mechanism. Lastly, the mediation of intracellular $\mathrm{Ca}^{2+}$ release by PKG could be involved with those observations. Song et al. [14] studied the effects of CA on myocardial injury (MI), using an in vivo model. CA treatment deceased the biochemical (CK-MB and LDH) and inflammatory markers of MI (TNF- $\alpha$ and IL-6) and increased the NO levels, which resulted in the reduction of cardiac histological abnormalities induced by isoproterenol. These benefits were related, at least in part, to the improvement of NO synthesis and the antioxidant effect of this compound. 


\subsection{Cinnamyl Alcohol}

Cinnamyl alcohol is a phenylproppanoid that occurs in numerous natural products in free state or as an ester in plants, such as cinnamon leaf, narcissus, and gardenia. This compound can also be obtained by the hydrogenation of cinnamic aldehyde. The vasodilatory propriety of cinnamyl alcohol (CAL) was evaluated by Kang et al. [47]. They used aortic rings, the cell cultures of human aortic smooth muscle cells and human umbilical vein endothelial cells. The results on the aortic rings showed an endothelium-dependent vasodilation. This effect was reduced by L-NAME, glibenclamide and methylene blue pre-treatment, which indicated the role of $\mathrm{NO}, \mathrm{K}^{+}$channel and guanylylcyclase, respectively, on the vasodilatory activity of CAL. It was also demonstrated that CAL promoted cGMP accumulation and the augmentation of PKG1 levels, and interfered with the Rho-kinase pathway. Therefore, the endothelium-dependent vasodilation induced by CAL is related with the NO-cGMP-PKG pathway in rat thoracic aorta, resulting in activation of $\mathrm{K}^{+}$channels and an inhibition of the Rho-kinase pathway.

\section{5. $\alpha$-Bisabolol}

$\alpha$-Bisabolol is a monocyclic sesquiterpene tertiary alcohol, which has a weak sweet, floral aroma. It is found in substantial amounts in the essential oils of Matricaria chamomilla, Salvia runcinata, Eremanthus erythropappus, Myoporum grassifolium, and Vanillosmopsis sp [48]. Studies that evaluated the vasorelaxant proprieties of $(-)-\alpha$-bisabolol (BS) were concentrated on the aortic and mesenteric arteries. De Siqueira et al. [49] observed the relaxant action of BS in a wide range of smooth muscle preparations, with a higher pharmacological potency in the mesenteric vessels. Pre-contracted aortic rings also showed relaxation with BS administration. Later, the same group demonstrated the BS-induced vascular relaxation mechanism involved with the calcium influx through voltage-dependent channels [50]. Calcium-dependent vascular relaxation was also observed in porcine coronary and splenic arteries once the withdrawal of the calcium from the medium completely eliminated the BS-induced vascular relaxation [51]. Therefore, the studies that were conducted have demonstrated that BS promoted vasorelaxation by inhibiting the calcium influx through voltage-dependent channels. The evaluation of the molecular model of the $\beta$-subunit isoform of voltage-gated L-type $\mathrm{Ca}^{2+}$ channel $(\operatorname{Cav} \beta 2 a)$ demonstrated that BS interacted preferentially with this channel subunit and promoted the uncoupling of the Cav $\beta 2$ a subunit from the $\alpha$-interaction domain (AID). However, the authors do not exclude that BS could have also acted as a negative allosteric inhibitor.

\subsection{Carvacrol}

Carvacrol is a monoterpene phenol found in many essential oils. The compound is an isomer of thymol. Shabir et al. [52] observed that carvacrol decreased the hypercontraction induced by lead ( $\mathrm{Pb}$ II) in the aortic rings of rats at a concentration of $100 \mu \mathrm{mol} / \mathrm{L}$. The incubation of carvacrol with apocynin, which is an inhibitor of NADPH oxidase enzyme, did not promote any change in the vasodilatory response. However, co-incubation with L-NAME decreased the effect of carvacrol, which indicated that the relaxant effect of this compound was mediated by an increase in NO synthesis. Pires et al. [13] used cell cultures from parenchymal arterioles and tested the effect of carvacrol on calcium permeability on the transient receptor potential vanilloid (TRPV). The authors showed that carvacrol promoted an increased influx of calcium by activating the TRPV3 channel. Therefore, this calcium influx through the TRPV3 channel, which is important to activate intermediate (IK) and small-conductance $\mathrm{Ca}^{2+}$-activated $\mathrm{K}^{+}(\mathrm{SK})$ channels and causes hyperpolarization, may contribute to carbachol-endothelium dependent vascular relaxation. In vivo studies conducted by Dantas et al. [53] demonstrated that carvacrol induced hypotension and bradycardia in non-anesthetized Wistar rats. The mechanism apparently involved vasorelaxation through the reduction of $\mathrm{Ca}^{2+}$ influx by changes in voltage-dependent, transient receptor potentials and store/receptor operator channels (SOCs/ROCs). Taken together, these studies 
demonstrate that Carvacrol can cause vascular relaxation by an endothelium-dependent mechanism that involves the $\mathrm{NO}$ and $\mathrm{Ca}^{2+}$ pathways.

\subsection{Borneol}

Borneol is a cyclic monoterpene alcohol extracted from Cinnamomum camphora (L.) and other plants [54]. Silva-Filho et al. [55] demonstrated that borneol promoted the relaxation of aortic rings that were pre-contracted with phenylephrine or $\mathrm{KCl}^{-}$in a concentration-dependent and endothelium-independent manner. Additionally, the pre-incubation with $\mathrm{K}^{+}$channel blockers attenuated the borneol-induced vasorelaxation. Borneol also interfered with intracellular calcium mobilization. Bai et al. [56] observed that a borneol-rich extract at a concentration of $1 \mathrm{mg} / \mathrm{mL}$ promoted relaxation, with total relaxation that was obtained at $10 \mathrm{mg} / \mathrm{mL}$. It was observed that a Suxiao Jiuxin Pill was able to promote vasorelaxation by both endothelium-dependent and -independent mechanisms. Wu et al. [57] conducted an in vivo study to determine if borneol had neuroprotective properties against ischemic stroke. The anti-inflammatory proprieties of borneol were demonstrated in this study. Borneol alone $(0.8 \mathrm{mg} / \mathrm{kg})$ was able to promote a reduction on the protein expression of pro-inflammatory markers (TNF- $\alpha$, iNOS, IL-1 $\beta$ and COX-2). Additionally, borneol promoted a reduction of the infarct area in a dose-dependent manner $\left(\mathrm{IC}_{50}: 0.36 \mathrm{mg} / \mathrm{kg}\right)$. Together, these results demonstrated the neuroprotective effects of borneol and promoted an indirect increase of the scavengers of ROS, and once the expression of iNOS was reduced the production of NO decreased.

\subsection{Carvone}

Carvone is a monoterpene ketone and the main active component of the oil of Mentha spicata. The carvones ((+)- and (-)-forms) are probably the most versatile terpene chirogens and suitable starting materials in stereoselective synthesis, especially terpenes [58]. The most well-known source of $(-)-(R)$-carvone is spearmint oil. Its enantiomer is a constituent of dill and caraway oils [59]. To investigate the effect of carvone on conductance arteries, Kundu et al. [60] demonstrated that this terpenoid was capable of promoting vasorelaxation on pre-contracted aortic rings, even when the artery was exposed to metals (arsenic and mercury). The antioxidant proprieties of carvone contributed to this vasorelaxant effect. However, the effect of carvone on calcium voltage-dependent channels was more important than its ROS scavenger or NO synthesis actions. Using aortic rings and guinea pig tracheas, De Sousa et al. [61] showed that there was no difference in the pharmacological action of (+)- and (-)-enantiomers of carvone, both forms presented a vasorelaxant action. Furthermore, it seems that the action was directly on the smooth muscle, since it was not reduced in the endothelium deprived rings.

\subsection{Eugenol}

This phenylpropanoid is used as an ingredient in cosmetics, perfumes, and pharmaceutical and dental preparations [62]. Kundu et al. [60] demonstrated that eugenol presented antioxidant proprieties and could promote a vasorelaxant effect, and a calcium blockade in high concentrations. The protective effect was observed in arteries that were exposed to heavy metal (As and $\mathrm{Hg}$ ). Along the same line, Shabir et al. [52] examined that the effects of Eugenol were examined in $\mathrm{Pb}$ (II)-hypercontracted aortic rings. The authors observed that $\mathrm{Pb}$ (II) induced hypercontraction through the depletion of $\mathrm{NO}$ and by increased reactive oxygen species (ROS). Eugenol promoted relaxation of $\mathrm{Pb}$ (II) hypercontracted aortic rings by increased NO bioavailability. This effect was probably mediated by the antioxidant proprieties of this compound. Peixoto-Neves et al. [63] showed that Eugenol promoted a concentration-dependent dilation of the cerebral arteries by an inhibition of Calcium voltage-dependent channel, which was confirmed by patch-clamp studies. 


\subsection{1-Nitro-phenylethane}

The 1-nitro-phenylethane (NP) is the first nitro compound isolated from essential oil, and one of the few natural products containing this functional group [64]. The cardiovascular effect of this compound, isolated from A. canelilla essential oil and others plants, was tested in vivo by Interaminense et al. [65]. NP promoted bradycardic and hypotensive responses after a bolus injection. That response was completely eradicated after cervical bivagotomy. The tests that were made with capsaicin and methylatropine suggested that the mechanism of action used by NP was mediated by both a vagal reflex and a cholinergic mechanism. Additionally, the application of NP directly on the heart shows that an effect of pulmonary C-fibers could also be involved.

\subsection{Auraptene}

Auraptene is a coumarin contained in the peels of citrus fruits such as Citrus paradise [66]. Razavi et al. [67] studied the effect of the chronic administration of auraptene on heart rate and blood pressure after eight weeks of treatment of normo- and hypertensive rats using the DOCA-Salt model of hypertension. They observed a dose- and time-dependent decrease in blood pressure in hypertensive rats and no changes in heart rate. While promising, the study failed to provide mechanisms since a biomolecular study was not performed.

\subsection{Citral}

Citral is a mixture of the isomeric aldehydes geranial and neral, which occurs in plants and citrus fruits. Pereira et al. [68] used aortic rings to investigate the vasorelaxant proprieties of this monoterpene. The authors showed that this compound promoted vasodilation in phenylephrine pre-contracted rings using an endothelium-independent mechanism. The results suggested that citral promoted relaxation by changing calcium dynamics, which is an effect that occurs once citral-inhibited contractions by both high $\mathrm{K}^{+}$and phenylephrine manifest. However, the study did not investigate the effects of citral on calcium receptors.

\subsection{Citronellal}

The monoterpene citronellal is a major component of the essential oils in various aromatic species, such as Cymbopogon winterianus Jowitt (Java citronella), Corymbia citriodora (Hook.) K.D. Hill, and C. nardus L. [69]. Cardiovascular properties of citronellal were evaluated in an NO-inhibition model of experimental hypertension. Mean arterial pressure (MAP) was reduced by oral acute citronellal administration. Citronellal also induced vasorelaxation of the mesenteric arteries of rats using an endothelium-independent mechanism. Although the exact mechanism of the vasodilatory action of citronellal was not conclusive, it is possible to state that the hypotensive effect should be related to its vasodilatory action.

\subsection{Farnesene}

Farnesene is one of the major compounds of the German essential oil chamomile. The action of this sesquiterpene on vascular tone was investigated using porcine coronary and splenic arteries. It was demonstrated that farnesene did not promote a vasorelaxant effect even when concentrations up to $30 \mu \mathrm{M}$ were used [51].

\subsection{Limonene}

Limonene is a monoterpene found in citrus fruits, especially in orange and lemon, with high concentration in their essential oils [70,71]. De Sousa et al. [61] investigated the effects of limonene in guinea pig tracheas and rat aortas. The authors observed that the compound produced relaxant effects on the tracheas and aortic rings independent of the endothelium. In this study, both (+)-limonene and 
(-)-limonene enantiomers were used, and no differences were observed. This indicated that limonene could promote antispasmodic effects on the smooth muscle of the trachea.

\subsection{Linalool}

The monoterpene linalool (LO) is the major constituent (87.7\%) of Rosewood Oil (EOAR). De Siqueira et al. [72] observed that EOAR induced hypotension and bradycardia in awakened animals that were abolished by pre-treatment with methylatropine. Additionally, dose-dependent EOAR blunted the phenylephrine-induced contraction of the aortic rings. Isolated LO reduced the hypercontraction of aortic segments induced by heavy metals, such as As and $\mathrm{Hg}$, and involved the enhancement of NO synthesis and the blockade of voltage-dependent calcium channels [60]. Deep investigation of the mechanism of action of LO indicated further participation of soluble guanylyl cyclase and $\mathrm{K}^{+}$channel on its vasorelaxant effects [73].

\subsection{Linalyl Acetate}

The monoterpene ester linalyl acetate (LA) mobilized the intracellular calcium concentration ([Ca]i) in cultured vascular endothelial (EC) or in mouse vascular smooth muscle (MOVAS) cells. In EC, LA induced a transient increase followed by a sustained decrease in [Ca]i, whereas in MOVAS the increase remained unchanged. LA blocks the extracellular calcium influx in EC, but not in MOVAS. Therefore, LA differently affects the endothelium and smooth muscle cells and its effect on EC may explain its protective effect against endothelium dysfunction associated with cardiovascular diseases [74].

\subsection{Menthol}

Menthol is a monoterpene alcohol found in Mentha species such as M. piperita and M. arvensis [75]. Cheang et al. [76] used different arterial segments (aortae, coronary and mesenteric) to investigate the proprieties of the menthol to produce vasorelaxation. This monoterpene produced concentration-dependent and endothelium independent vasorelaxation. The contraction induced by $\mathrm{CaCl}_{2}$ was suppressed by menthol in a similar way as nifedipine (an L-type $\mathrm{Ca}^{2+}$ channel inhibitor) and indicated that menthol could affect this kind of channel. This study demonstrated that the vasorelaxant proprieties of menthol were not affected by cGMP or NO. Therefore, the vasorelaxation induced by menthol was probably caused by direct action on calcium dynamics.

\subsection{N-Butylidenephthalide}

$N$-Butylidenephthalide (BP) is obtained from the volatile oil of Angelica sinensis [77]. The effects of this compound in angiogenesis and cell proliferation in vitro and ex vivo were evaluated by Yeh et al. [77]. The researchers showed that this compound was capable of a concentration-dependent inhibition of endothelial proliferation, endothelial wound healing, and endothelial tube formation on human umbilical vein endothelial cells (HUVEC). The researchers also investigated the mechanism of action and determined that BP promoted apoptosis and an increased maintenance of the cell cycle during the G0-G1 phase. Additionally, BP decreased the capillary sprouting of the aorta and vascularization of zebrafish. Together, these results indicate the anti-angiogenic effect of BP.

\subsection{Rotundifolone}

Several studies using the essential oil of Mentha $x$ villosa showed its hypotensive effect in a dose-dependent manner in hypertensive rats (DOCA-salt hypertensive rats), which is probably associated with a vasorelaxative activity [78,79]. Similarly, hypotensive properties also were observed with the monoterpene rotundifolone, the main constituent of the essential oil of Mentha $x$ villosa, comprising approximately $63 \%$ of its content. Rotundifolone promotes a concentration-dependent vasorelaxant effect on the superior mesenteric arteries of rats. The mechanism by which rotundifolone 
promoted this relaxation was investigated using patch-clamp techniques. The experiment demonstrated that rotundifolone probably acted by calcium-activated potassium $\left(\mathrm{BK}_{\mathrm{Ca}}\right)$ channel activation, once tetraethylammonium (TEA) eradicated the observed relaxation. However, this mechanism of action seemed to be more important at low doses and on conducting arteries (aorta). Additionally, changes on the L-type $\mathrm{Ca}^{2+}$ channels at high concentrations could also precipitate the mechanism by which rotundifolone caused vascular relaxation.

\subsection{1. $\alpha$-Terpineol}

The in vivo effect of the monoterpene $\alpha$-terpineol was evaluated by Sabino et al. [80] who used the model of hypertension induced by L-NAME. Therefore, it was demonstrated that $\alpha$-terpineol was capable of inducing a dose-dependent hypotension in awake animals. Likewise, when mesenteric rings were used, the researchers showed that this compound produced vasorelaxant effects independent of the endothelium. Those vasorelaxant effects could be attributed, at least in part, to the inhibition of voltage-dependent calcium channels. Additionally, treatment with $\alpha$-terpineol for seven days promoted an induced antioxidant effect in the animals treated with L-NAME. The values of SOD, catalase and glutathione peroxidase activity were restored to values similar to the control groups, which indicated the antioxidant capacity of $\alpha$-terpineol.

The in vitro and in vivo cardiovascular effects of the chemical constituents of essential oils are shown in Tables 1 and 2.

Table 1. In vitro cardiovascular effects of the chemical constituents of essential oils.

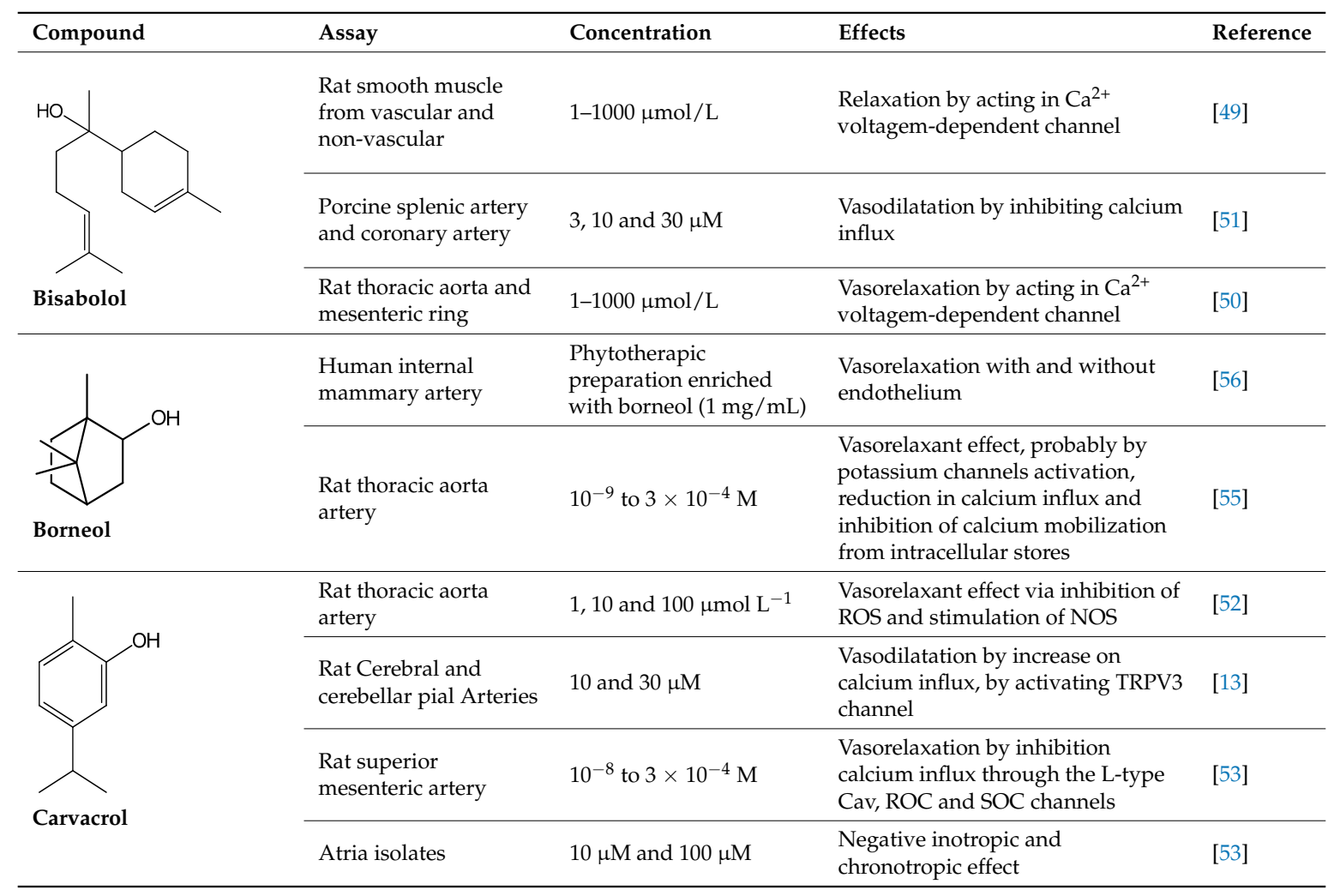


Table 1. Cont.

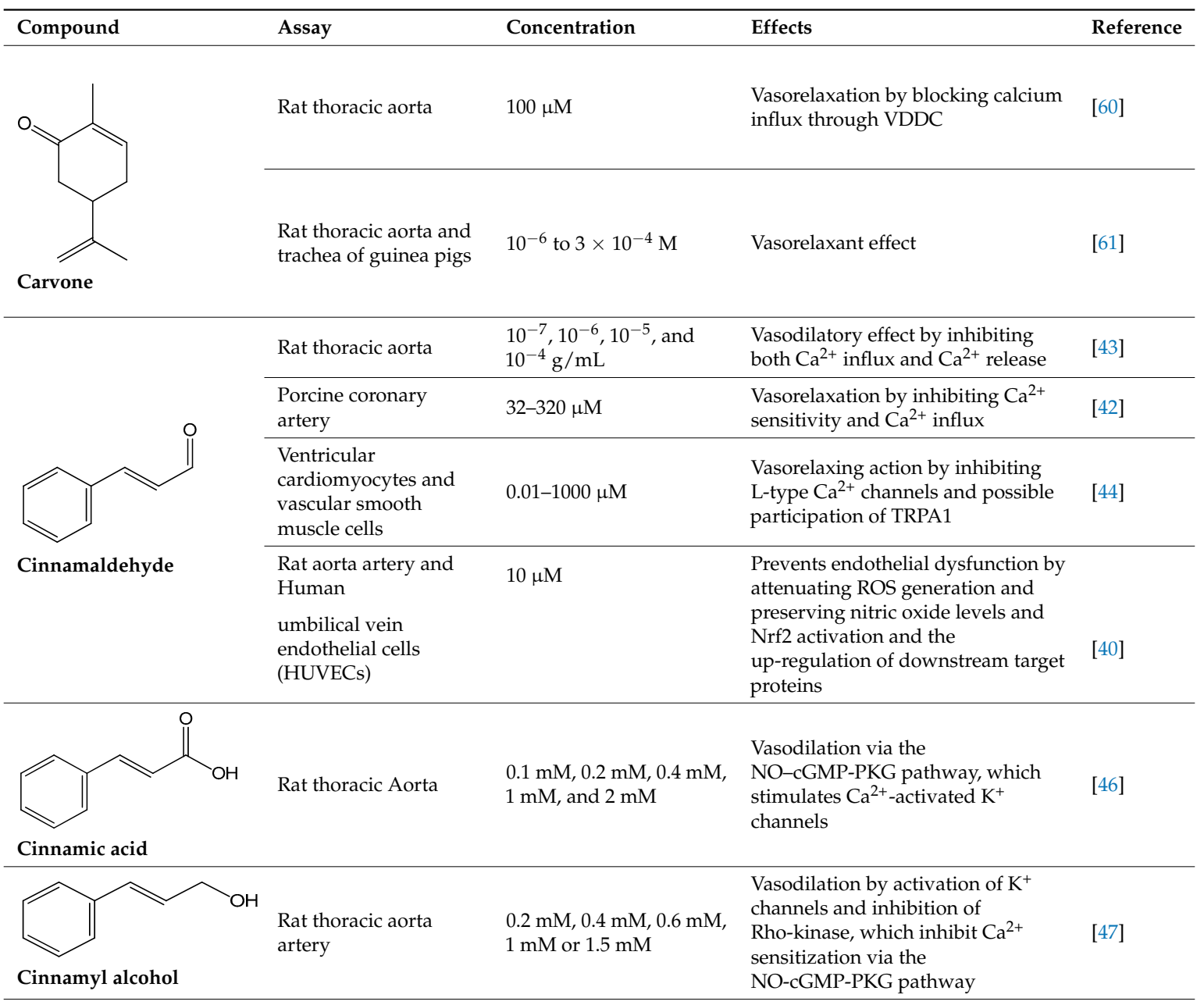<smiles>CC(C)=CCCC(C)=CCOC(C)=CC=O</smiles>

Rat thoracic Aorta artery

0.6 to $6 \mathrm{mM}$ (geranial) (neral)

Citral (= geranial + neral)
Vasorelaxation by reduced the calcium influx by the blockade of voltage dependent L-type $\mathrm{Ca}^{2+}$ channels

\begin{tabular}{|c|c|c|c|c|}
\hline & Rat atria Muscle & $1,3,5,7$, and $10 \mathrm{mM}$ & $\begin{array}{l}\text { Increase in resting tension by } \\
\text { cooperative activation of cardiac } \\
\text { thin filaments by strongly attached } \\
\text { cross-bridges (rigor state) }\end{array}$ & [63] \\
\hline & Rat atria Muscle & $1,3,5,7$, and $10 \mathrm{mM}$ & $\begin{array}{l}\text { Increase in resting tension by } \\
\text { cooperative activation of cardiac } \\
\text { thin filaments by strongly attached } \\
\text { cross-bridges (rigor state) }\end{array}$ & \\
\hline & $\begin{array}{l}\text { Rat thoracic } \\
\text { aorta artery }\end{array}$ & 1,10 and $100 \mu \mathrm{mol} \mathrm{L}^{-1}$ & $\begin{array}{l}\text { Vasorelaxant effect via inhibition of } \\
\text { ROS and stimulation of NOS }\end{array}$ & [52] \\
\hline \multirow{2}{*}{ Eugenol } & $\begin{array}{l}\text { Rat thoracic } \\
\text { aorta artery }\end{array}$ & $100 \mu \mathrm{M}$ & $\begin{array}{l}\text { Vasorelaxation by inhibiting ROS } \\
\text { and elevating NO }\end{array}$ & [60] \\
\hline & Rat cerebral artery & $100 \mu \mathrm{M}$ & $\begin{array}{l}\text { Vasorelaxation by inhibiting } \\
\text { voltage-dependent } \mathrm{Ca}^{2+}\end{array}$ & [63] \\
\hline
\end{tabular}


Table 1. Cont.

\begin{tabular}{|c|c|c|c|c|}
\hline Compound & Assay & Concentration & Effects & Reference \\
\hline & $\begin{array}{l}\text { Porcine splenic artery } \\
\text { and coronary artery }\end{array}$ & 3,10 and $30 \mu \mathrm{M}$ & $\begin{array}{l}\text { Vasodilatation by inhibiting } \\
\text { calcium influx }\end{array}$ & [51] \\
\hline
\end{tabular}

Rat thoracic aorta and trachea of guinea pigs

$10^{-6}$ to $3 \times 10^{-4} \mathrm{M} \quad$ Vasorelaxant effect

[61]<smiles>C=C(C)C(CC)CC</smiles>

Limonene

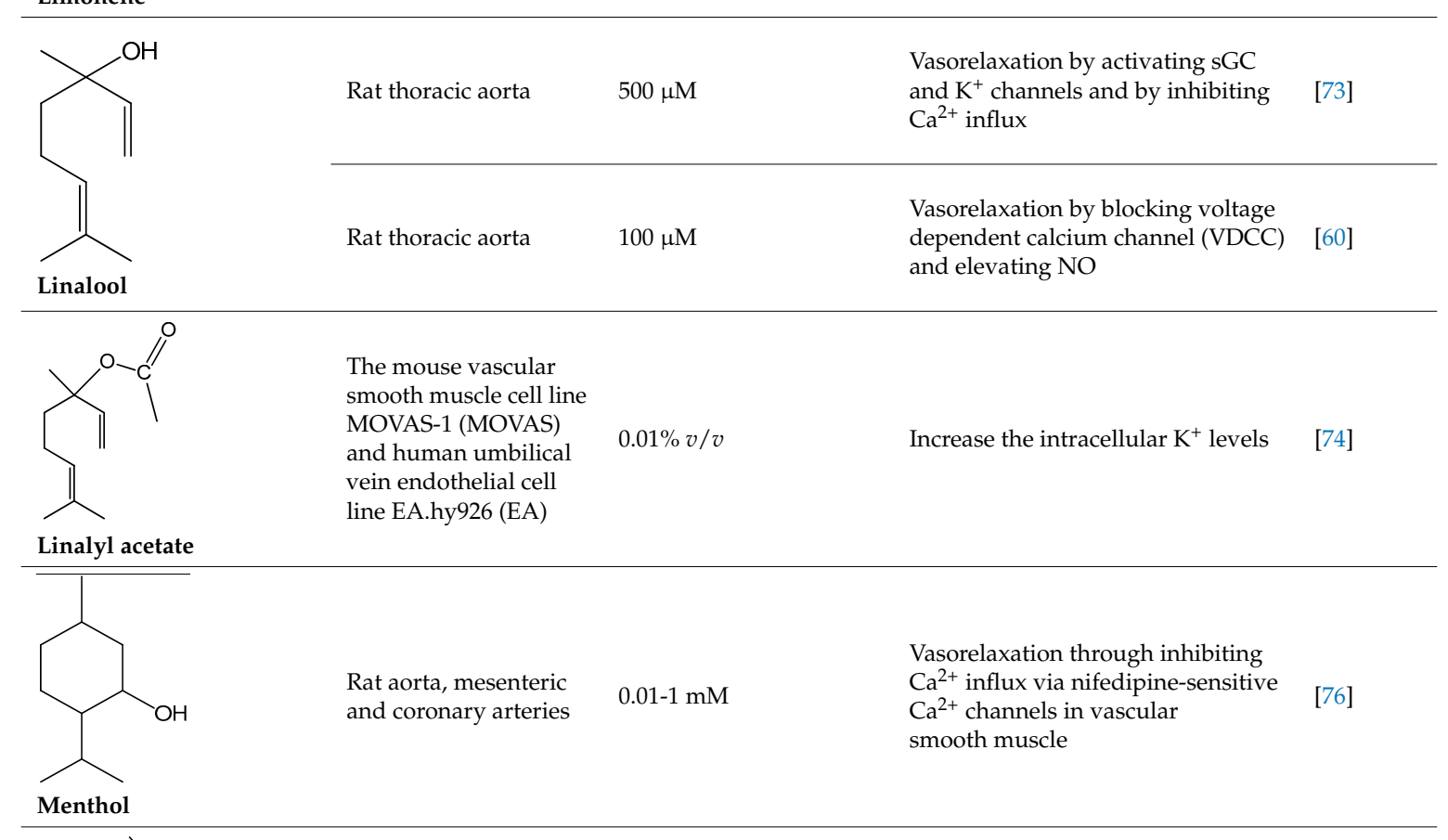<smiles>[131I-]</smiles>

Human umbilical vein endothelial cells (HUVECs)
Anti-angiogenic activities by increase of maintaining cell cycle on

G0-G1 phase, and promoting apoptosis
[77]

Vasorelaxation through activation of

Rat superior mesenteric artery

$10^{-7}$ to $3 \times 10^{-3} \mathrm{M}$ $\mathrm{BK}_{\mathrm{Ca}}$ channels and by the inhibition of $\mathrm{Ca}^{2+}$ entry through L-type

$\mathrm{Ca}^{2+}$ channels 
Table 2. In vivo cardiovascular effects of the chemical constituents of essential oils.

\begin{tabular}{llll}
\hline Compound & Model & Dose & Effects \\
\hline $\mathrm{NO}_{2}$ & $\begin{array}{l}\text { Reference } \\
\text { Spontaneously } \\
\text { hypertensive rats (SHR) }\end{array}$ & $\begin{array}{l}\text { Promotes bradycardic and } \\
\text { hypotensive responses after in } \\
\text { bolus application. The mechanism } \\
\text { suggested is by cholinergic and } \\
\text { vagal reflex activation }\end{array}$ \\
\hline
\end{tabular}

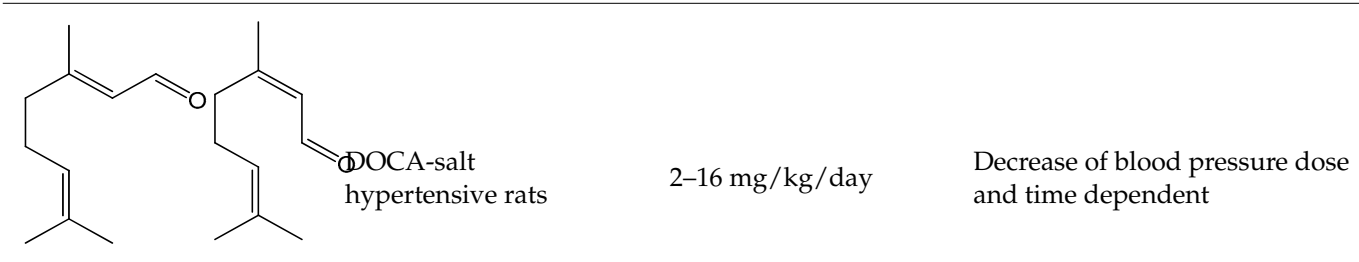

(geranial) (neral)

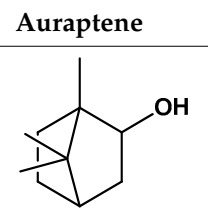

Borneol

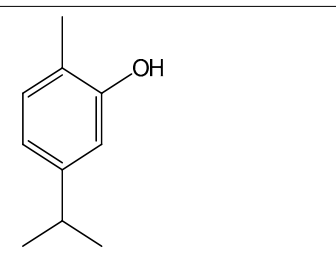

Wistar rats $\quad 1-20 \mathrm{mg} / \mathrm{kg}$

ischemia by intraluminal

middle cerebral artery

$0.8 \mathrm{mg} / \mathrm{kg}$

occlusion (MCAO)

(1)

Carvacrol

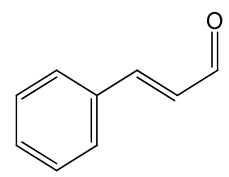

Isoproterenol model of myocardial ischemia

$22.5,45$ and $90 \mathrm{mg} / \mathrm{kg}$

Decrease of cardiac injury and pro-inflammatory cytokines after

per-treatment (14 days),

additionally an increase of $\mathrm{NO}$

and SOD levels of heart tissue

Cinnamaldehyde<smiles>O=C(O)/C=C/c1ccccc1</smiles>

Isoproterenol model of myocardial ischemia

$37.5,75$ and $150 \mathrm{mg} / \mathrm{kg}$

Decrease of biochemical markers of myocardial infarct and increase

of $\mathrm{NO}$ levels. Indicating

antioxidant proprieties of $\mathrm{CD}$

Cinnamic acid<smiles>CC(C)=CCCC(C)CC=O</smiles>
and normotensive rats

$5,10,20$, and $40 \mathrm{mg} / \mathrm{kg}$ in bolus and 200 $\mathrm{mg} / \mathrm{kg}$ orally
In bolus promotes hypotensive and bradycardic effects of normotensive rats. Treatment of L-NAME hypertensive rats promotes decrease of MAP. The results suggest that muscarinic receptors could be involved

Citronellal<smiles>C=CC(C)(O)CCC=C(C)C</smiles>

They evaluate the essential oil of Rosewood enriched with linalool.

Normotensive rat $\quad 1-20 \mathrm{mg} / \mathrm{kg}$

In bolus treatment promotes biphasic hypotension and

bradycardic responses by vagal

reflex and cholinergic mechanism 
Table 2. Cont.

\begin{tabular}{|c|c|c|c|c|}
\hline Compound & Model & Dose & Effects & Reference \\
\hline $\mathrm{OH}$ & $\begin{array}{l}\text { L-NAME } \\
\text { hypertensive rats }\end{array}$ & 25-100 mg/kg/day & $\begin{array}{l}\text { Cardioprotective effect by } \\
\text { induced hypotension and } \\
\text { antioxidant potential by restoring } \\
\text { antioxidant enzyme activities } \\
\text { (catalase and } \\
\text { glutathione peroxidase) }\end{array}$ & {$[80]$} \\
\hline$\alpha$-Terpineol & & & & \\
\hline
\end{tabular}

Pre-treatment with thymoquinone<smiles>CC1=CC(=O)C(C(C)C)=CC1=O</smiles>

Thymoquinone
Airway inflammation by acute exposure to diesel exhaust particles (DEP)
$0.01-0.1 \mathrm{mg} / \mathrm{mL}$ prevents the worse effects promoted by DEP such as leukocytosis, increase of IL-6 and decrease of SOD plasma activity. The platelet numbers and prothrombotic events were also decreased

Antioxidant and Cardioprotective effects by decrease of LDH levels and TBARS activity. The SOD activity was increased to almost normal levels. The GSH/GSSG ratio decreased gradually and returned to near normal levels with corresponding increases in the dose

Reduction of oxidative stress determined by Total Oxidant Status and Oxidative Stress Index in blood samples. Decreased of histopathologic injury in in lung, renal, and heart tissues

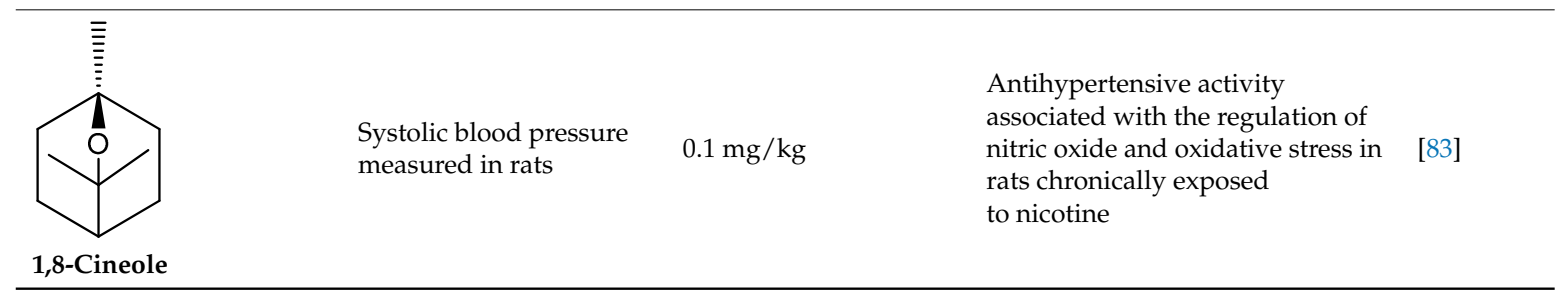

\subsection{1,8-Cineole}

The effect of cyclic monoterpene 1,8-cineole was investigated on systolic blood pressure (SBP) and oxidative stress in rats chronically exposed to nicotine. The dose of $0.1 \mathrm{mg} / \mathrm{kg}$ of this monoterpene significantly reduced SBP, while, at the dose of $1.0 \mathrm{mg} / \mathrm{kg}$, there was an increase of plasma nitrite concentrations. At doses of $0.01 \mathrm{mg} / \mathrm{kg}$ and $0.1 \mathrm{mg} / \mathrm{kg}, 1,8$-cineole also antagonized nicotine-induced lipid peroxidation. It has been suggested that the regulation of nitric oxide and oxidative stress in rats should contribute to the antihypertensive effect of 1,8-cineole [83].

\section{Conclusions}

Essential oils are a new option of bioactive substances in animal models that are being used in the study of new candidates for cardiovascular drugs. Due to the diversity of chemical structures and mechanisms of action, such as blockade of voltage dependent L-type $\mathrm{Ca}^{2+}$ channels, cholinergic and vagal reflex activation, and participation of muscarinic receptors, it is not possible to establish a principal chemical characteristic of cardiovascular activity. The lipid solubility and volatility are common properties of these substances. However, several compounds have high pharmacological potency, for example 1,8-cineole and borneol. Pharmacological evaluation of the synthetic derivatives of 
these constituents appears to be an interesting way to optimize the pharmacologic profile and advance the knowledge to promote accomplishing prototypes for new cardiovascular drugs. In addition, the simplicity of the chemical structures of the bioactive compounds may result in the preparation of low cost drug candidates.

Acknowledgments: This work was supported by the Brazilian agencies: Conselho Nacional de Desenvolvimento Científico e Tecnológico (CNPq), Coordenação de Aperfeiçoamento de Pessoal de Nível Superior (CAPES) and Fundação de Amparo à Pesquisa e Inovação do Espírito Santo (FAPES).

Author Contributions: Flávio Rogério da Nóbrega surveyed the data and formatted the manuscript. Girlandia Alexandre Brasil and Denise Coutinho Endringer wrote the pharmacological part of the review. Tadeu Uggere de Andrade was responsible for the analysis of these data and revision of pharmacological writing. Damião Pergentino de Sousa wrote the chemical content, planned and coordinated the study.

Conflicts of Interest: The authors declare no conflict of interest.

\section{Abbreviations}

\begin{tabular}{|c|c|}
\hline AID & Alfa $(\alpha)$ Interaction Domain \\
\hline $\mathrm{BP}$ & $N$-Butylidenephthalide \\
\hline BS & $(-)-\alpha$-Bisabolol \\
\hline CAL & Cinnamyl Alcohol \\
\hline $\operatorname{Cav} \beta 2 \mathrm{a}$ & $\beta$-Subunit isoform of voltage-gated L-type $\mathrm{Ca}^{2+}$ channel \\
\hline cGMP & Cyclic guanosine monophosphate \\
\hline CK-MB & Creatine kinase $\mathrm{MB}$ \\
\hline CVD & Cardivascular diseases \\
\hline DOCA & Deoxycorticosterone acetate \\
\hline EC & Cultured vascular endothelial \\
\hline EDHF & Endothelium-Derived Hyperpolarizing Factor \\
\hline eNOS & Endothelial NO Synthase \\
\hline EOAR & Rosewood Oil \\
\hline GR & Glutathione Reductase \\
\hline GSH/GSSG & Reduced or Oxidized Glutathione ratio \\
\hline HUVEC & Human Umbilical Vein Endothelial Cells \\
\hline IK & Active Intermediate \\
\hline IL-1 $\beta$ & Interleukin $1 \beta$ \\
\hline IL-6 & Interleukin 6 \\
\hline iNOS & Inducible NO Synthase \\
\hline LA & Linalyl Acetate \\
\hline $\mathrm{LDH}$ & Lactate Dehydrogenase \\
\hline L-NAME & $N(\omega)$-Nitro-L-Arginine Methyl Ester \\
\hline $\mathrm{LO}$ & Linalool \\
\hline MAP & Mean Arterial Pressure \\
\hline MI & Myocardial Injury \\
\hline MOVAS & Mouse Vascular Smooth Muscle \\
\hline NCD & Non Communicable Diseases \\
\hline $\mathrm{NO}$ & Nitric oxide \\
\hline NP & 1-Nitro-Phenylethane \\
\hline Nrf2 & NF-E2-related factor 2 \\
\hline PKG & Protein Kinase G \\
\hline RAS & Renin-angiotensin Aldosterone System \\
\hline ROC & Receptor Operator Channels \\
\hline ROS & Reactive Oxygen \\
\hline SBP & Species Systolic Blood Pressure \\
\hline SK & Small-conductance $\mathrm{Ca}^{2+}$-activated $\mathrm{K}^{+}$ \\
\hline SKCa/IKCa & Calcium Activated Potassium Channels \\
\hline SOCs & Store Operator Channels \\
\hline
\end{tabular}




$\begin{array}{ll}\text { SOD } & \text { Superoxide Dismutase } \\ \text { TBARS } & \text { Thiobarbituric Acid Reactive Substances } \\ \text { TEA } & \text { Tetraethylammonium } \\ \text { TNF- } \alpha & \text { Tumor Necrosis Factor alpha } \\ \text { TQ } & \text { Thymoquinone } \\ \text { TRPA1 } & \text { Transient Receptor Potential Ankyrin 1 } \\ \text { TRPV } & \text { Transient Receptor Potential Vanilloid } \\ \text { VCM } & \text { Ventricular Cardiac Myocytes } \\ \text { VOCC } & \text { Voltage-Operated Calcium Channel } \\ \text { VSMC } & \text { Vascular Smooth Muscle Cells }\end{array}$

\section{References}

1. World Health Organization. Global Health Estimates: Deaths by Cause, Age, Sex and Country. Available online: http:/ / www.who.int/healthinfo/global_burden_disease/en/ (accessed on 3 May 2017).

2. World Health Organization. Global Status Report on Noncommunicable Diseases 2014. Available online: http:/ /apps.who.int/iris/bitstream/10665/148114/1/9789241564854_eng.pdf?ua=1 (accessed on 3 May 2017).

3. Matthew, J.R.; Kaye, A.D. Complementary and alternative medicine and cardiovascular disease: An evidencebased review. Evid. Based Complement. Altern. Med. 2013, 2013, 1-8.

4. Newman, D.J.; Cragg, G.M. Natural products as sources of new drugs from 1981 to 2014. J. Nat. Prod. 2016, 79, 629-661. [CrossRef] [PubMed]

5. Vinson, J.A.; Dabbagh, Y.A.; Serry, M.M.; Jang, J. Plant flavonoids, especially tea flavonols, are powerful antioxidants using an in vitro oxidation model for heart disease. J. Agric. Food Chem. 1995, 43, 2800-2802. [CrossRef]

6. Dandona, P.; Ghanim, H.; Brooks, D.P. Antioxidant activity of carvedilol in cardiovascular disease. J. Hypertens. 2007, 25, 731-741. [CrossRef] [PubMed]

7. Korantzopoulos, P.; Kolettis, T.M.; Galaris, D.; Goudevenos, J.A. The role of oxidative stress in the pathogenesis and perpetuation of atrial fibrillation. Int. J. Cardiol. 2007, 115, 135-143. [CrossRef] [PubMed]

8. Suen, J.; Thomas, J.; Kranz, A.; Vun, S.; Miller, M. Effect of flavonoids on oxidative stress and inflammation in adults at risk of cardiovascular disease: A systematic review. Healthcare (Basel) 2016, 4, 69. [CrossRef] [PubMed]

9. Cunha, F.V.; Gomes, B.S.; Neto, B.S.; Ferreira, A.R.; De Sousa, D.P.; De Carvalho Martins, M.C.; Oliveira, F.A. Ferulic acid ethyl ester diminished Complete Freund's Adjuvant-induced incapacitation through antioxidant and anti-inflammatory activity. Naunyn-Schmiedeberg's Arch. Pharmacol. 2016, 389, 117-130. [CrossRef] [PubMed]

10. Pires, L.F.; Costa, L.M.; De Almeida, A.A.; Silva, O.A.; Cerqueira, G.S.; De Sousa, D.P.; De Freitas, R.M. Is there a correlation between in vitro antioxidant potential and in vivo effect of carvacryl acetate against oxidative stress in mice hippocampus? Neurochem. Res. 2014, 39, 758-769. [CrossRef] [PubMed]

11. Rocha, N.F.; Oliveira, G.V.; Araújo, F.Y.; Rios, E.R.; Carvalho, A.M.; Vasconcelos, L.F.; Macêdo, D.S.; Soares, P.M.; De Sousa, D.P.; Sousa, F.C. (-)- $\alpha$-Bisabolol-induced gastroprotection is associated with reduction in lipid peroxidation, superoxide dismutase activity and neutrophil migration. Eur. J. Pharm. Sci. 2011, 44, 455-461. [CrossRef] [PubMed]

12. Silva, M.I.; Silva, M.A.; De Aquino Neto, M.R.; Moura, B.A.; De Sousa, H.L.; De Lavor, E.P.; De Vasconcelos, P.F.; Macêdo, D.S.; De Sousa, D.P.; Vasconcelos, S.M.; et al. Effects of isopulegol on pentylenetetrazol-induced convulsions in mice: possible involvement of GABAergic system and antioxidant activity. Fitoterapia 2009, 80, 506-513. [CrossRef] [PubMed]

13. Pires, P.W.; Sullivan, M.N.; Pritchard, H.A.; Robinson, J.J.; Earley, S. Unitary TRPV3 channel Ca ${ }^{2+}$ influx events elicit endothelium-dependent dilation of cerebral parenchymal arterioles. Am. J. Physiol. Heart CircPhysiol. 2015, 309, 2031-2041. [CrossRef] [PubMed]

14. Song, F.; Li, H.; Sun, J.; Wang, S. Protective effects of cinnamic acid and cinnamicaldehyde on isoproterenol-induced acute myocardial ischemia in rats. J. Ethnopharmacol. 2013, 150, 125-130. [CrossRef] [PubMed] 
15. Burgoyne, J.R.; Mongue-Din, H.; Eaton, P.; Shah, A.M. Redox signaling in cardiac physiology and pathology. Circ. Res. 2012, 111, 1091-1106. [CrossRef] [PubMed]

16. Zafar, R. An insight into pathogenesis of cardiovascular diseases. J. Cardiovasc. Dis. Diagn. 2015, 3, 1-7. [CrossRef]

17. Hertog, M.G.; Feskens, E.J.; Kromhout, D.; Hollman, P.C.; Katan, M.B. Dietary antioxidant flavonoids and risk of coronary heart disease: The Zutphen Elderly Study. Lancet 1993, 342, 1007-1011. [CrossRef]

18. Vinson, J.A.; Jang, J.; Dabbagh, Y.A.; Serry, M.M.; Cai, S. Plant polyphenols exhibit lipoprotein-bound antioxidant activity using an in vitro oxidation model for heart disease. J. Agric. Food Chem. 1995, 43, 2798-2799. [CrossRef]

19. Amorati, R.; Foti, M.C.; Valgimigli, L.J. Antioxidant activity of essential oils. Agric. Food Chem. 2013, 61, 10835-10847. [CrossRef] [PubMed]

20. Van de Braak, S.A.A.J.; Leijten, G.C.J.J. Essential Oils and Oleoresins: A Survey in the Netherlands and Other Major Markets in the European Union; CBI, Centre for the Promotion of Imports from Developing Countries: Rotterdam, The Netherlands, 1999; p. 116.

21. De Sousa, D.P. Analgesic-like activity of essential oils constituents. Molecules 2011, 16, 2233-2252. [CrossRef] [PubMed]

22. Sarmento-Neto, J.F.; Do Nascimento, L.G.; Felipe, C.F.; De Sousa, D.P. Analgesic potential of essential oils. Molecules 2016, 21, 20. [CrossRef] [PubMed]

23. De Almeida, R.N.; Agra, M.F.; Maior, F.N.; De Sousa, D.P. Essential oils and their constituents: Anticonvulsant activity. Molecules 2011, 16, 2726-2742. [CrossRef] [PubMed]

24. De Cássia da Silveira e Sá, R.; Andrade, L.N.; De Sousa, D.P. A review on anti-inflammatory activity of monoterpenes. Molecules 2013, 18, 1227-1254. [CrossRef] [PubMed]

25. De Cássia da Silveira e Sá, R.; Andrade, L.N.; De Sousa, D.P. Sesquiterpenes from essential oils and anti-inflammatory activity. Nat. Prod. Commun. 2015, 10, 1767-1774.

26. De Cássia da Silveira e Sá, R.; Andrade, L.N.; Dos Reis Barreto de Oliveira, R.; De Sousa, D.P. A review on anti-inflammatory activity of phenylpropanoids found in essential oils. Molecules 2014, 19, 1459-1480. [CrossRef] [PubMed]

27. Carvalho, A.A.; Andrade, L.N.; De Sousa, E.B.; De Sousa, D.P. Antitumor phenylpropanoids found in essential oils. Biomed. Res. Int. 2015, 392674. [CrossRef] [PubMed]

28. De Sousa, D.P. Bioactive Essential Oils and Cancer; Springer: New York, NY, USA, 2015.

29. Sobral, M.V.; Xavier, A.L.; Lima, T.C.; De Sousa, D.P. Antitumor activity of monoterpenes found in essential oils. Sci. World J. 2014, 953451. [CrossRef] [PubMed]

30. De Sousa, D.P.; De Almeida Soares Hocayen, P.; Andrade, L.N.; Andreatini, R. A systematic review of the anxiolytic-like effects of essential oils in animal models. Molecules 2015, 20, 18620-18660. [CrossRef] [PubMed]

31. Oliveira, F.A.; Andrade, L.N.; De Sousa, E.B.; De Sousa, D.P. Anti-ulcer activity of essential oil constituents. Molecules 2014, 19, 5717-5747. [CrossRef] [PubMed]

32. Santos, M.R.V.; Moreira, F.V.; Fraga, B.P.; De Sousa, D.P.; Bonjardim, L.R.; Quintans-Junior, L.J. Cardiovasular effects of monoterpenes: A review. Rev. Bras. Farmacogn. 2011, 21, 764-771. [CrossRef]

33. Aydin, M.S.; Kocarslan, A.; Kocarslan, S.; Kucuk, A.; Eser, İ.; Sezen, H.; Buyukfirat, E.; Hazar, A. Thymoquinone protects end organs from abdominal aorta ischemia/reperfusion injury in a rat model. Rev. Bras. J. Cardiovasc. 2015, 30,77-83. [CrossRef] [PubMed]

34. Nemmar, A.; Al-Salam, S.; Zia, S.; Marzouqi, F.; Al-Dhaheri, A.; Subramaniyan, D.; Dhanasekaran, S.; Yasin, J.; Ali, B.H.; Kazzam, E.E. Contrasting actions of diesel exhaust particles on the pulmonary and cardiovascular systems and the effects of thymoquinone. Br. J. Pharmacol. 2011, 164, 1871-1882. [CrossRef] [PubMed]

35. Randhawa, M.A.; Alghamdi, M.S.; Maulik, S.K. The effect of thymoquinone, an active component of Nigella sativa, on isoproterenol induced myocardial injury. Pak. J. Pharm. Sci. 2013, 26, 1215-1219. [PubMed]

36. Idris-Khodja, N.; Schini-Kerth, V. Thymoquinone improves aging-related endothelial dysfunction in the rat mesenteric artery. Naunyn-Schmiedeberg's Arch. Pharmacol. 2012, 385, 749-758. [CrossRef] [PubMed]

37. Ghayur, M.N.; Gilani, A.H.; Janssen, L.J. Intestinal, airway, and cardiovascular relaxant activities of thymoquinone. Evid. Based Complement. Altern. Med. 2012, 2012, 1-13. [CrossRef] [PubMed] 
38. Liao, J.C.; Deng, J.S.; Chiu, C.S.; Hou, W.C.; Huang, S.S.; Shie, P.H. Anti-inflammatory ACTIVITIES of cinnamomum cassia constituents in vitro and in vivo. Evid. Based Complement. Altern. Med. 2012, 2012, 429320. [CrossRef] [PubMed]

39. El-Bassossy, H.M.; Fahmy, A.; Badawy, D. Cinnamaldehyde protects from the hypertension associated with diabetes. Food Chem. Toxicol. 2011, 49, 3007-3012. [CrossRef] [PubMed]

40. Wang, F.; Pu, C.; Zhou, P.; Wang, P.; Liang, D.; Wang, Q.; Hu, Y.; Li, B.; Hao, X. Cinnamaldehyde prevents endothelial dysfunction induced by high glucose by activating Nrf2. Cell. Physiol. Biochem. 2015, 36, 315-324. [CrossRef] [PubMed]

41. He, M.; Siow, R.C.; Sugden, D.; Gao, L.; Cheng, X.; Mann, G.E. Induction of HO-1 and redox signaling in endothelial cells by advanced glycation end products: A role for Nrf2 in vascular protection in diabetes. Nutr. Metab. Cardiovasc. Dis. 2011, 21, 277-285. [CrossRef] [PubMed]

42. Raffai, G.; Kim, B.; Park, S.; Khang, G.; Lee, D.; Vanhoutte, P.M. Cinnamaldehyde and cinnamaldehydecontaining micelles induce relaxation of isolated porcine coronary arteries: Role of nitric oxide and calcium. Int. J. Nanomed. 2014, 21, 2557-2566. [CrossRef] [PubMed]

43. Xue, Y.L.; Shi, H.X.; Murad, F.; Bian, K. Vasodilatory effects of cinnamaldehyde and its mechanism of action in the rat aorta. Vasc. Health Risk Manag. 2011, 7, 273-280. [PubMed]

44. Alvarez-Collazo, J.; Alonso-Carbajo, L.; López-Medina, A.I.; Alpizar, Y.A.; Tajada, S.; Nilius, B.; Voets, T.; López-López, J.R.; Talavera, K.; Pérez-García, M.T.; et al. Cinnamaldehyde inhibits L-type calcium channels in mouseventricular cardiomyocytes and vascular smooth muscle cells. Pflugers Arch-Eur. J. Physiol. 2014, 466, 2089-2099. [CrossRef] [PubMed]

45. Vogt, T. Phenylpropanoid biosynthesis. Mol. Plant 2010, 3, 2-20. [CrossRef] [PubMed]

46. Kang, Y.H.; Kang, J.S.; Shin, H.M. Vasodilatory effects of cinnamic acid via the nitric oxide-cGMP-PKG Pathway in rat thoracic aorta. Phytother. Res. 2013, 27, 205-2011. [CrossRef] [PubMed]

47. Kang, Y.H.; Yang, I.J.; Morgan, K.G.; Shin, H.M. Cinnamyl alcohol attenuates vasoconstriction by activation of K+ channels via NO-cGMP-protein kinase G pathway and inhibition of Rho-kinase. Exp. Mol. Med. 2012, 44, 749-755. [CrossRef] [PubMed]

48. Kamatou, G.P.P.; Viljoen, A.M. A review of the application and pharmacological properties of $\alpha$-bisabolol and $\alpha$-Bisabolol Rich Oils. J. Am. Oil Chem. Soc. 2010, 87, 1-7. [CrossRef]

49. De Siqueira, R.J.; Freire, W.B.; Vasconcelos-Silva, A.A.; Fonseca-Magalhães, P.A.; Lima, F.J.; Brito, T.S.; Mourão, L.T.; Ribeiro, R.A.; Lahlou, S.; Magalhães, P.J. In vitro characterization of the pharmacological effects induced by (-)- $\alpha$-bisabolol in rat smooth muscle preparations. Can. J. Physiol. Pharmacol. 2012, 90, 23-35. [CrossRef] [PubMed]

50. De Siqueira, R.J.; Ribeiro-Filho, H.V.; Freire, R.S.; Cosker, F.; Freire, W.B.; Vasconcelos-Silva, A.A.; Soares, M.A.; Lahlou, S.; Magalhães, P.J. (-)- $\alpha$-Bisabolol inhibits preferentially electromechanical coupling on rat isolated arteries. Vasc. Pharmacol. 2014, 63, 37-45.

51. Roberts, R.E.; Allen, S.; Chang, A.P.; Henderson, H.; Hobson, G.C.; Karania, B.; Morgan, K.N.; Pek, A.S.; Raghvani, K.; Shee, C.Y.; et al. Distinct mechanisms of relaxation to bioactive components from chamomile species in porcine isolated blood vessels. Toxicol. Appl. Pharmacol. 2013, 272, 797-805. [CrossRef] [PubMed]

52. Shabir, H.; Kundu, S.; Basir, S.F.; Khan, L.A. Modulation of Pb (II) caused aortal constriction by eugenol and carvacrol. Biol. Trace Elem. Res. 2014, 161, 116-122. [CrossRef] [PubMed]

53. Dantas, B.P.; Alves, Q.L.; De Assis, K.S.; Ribeiro, T.P.; De Almeida, M.M.; De Vasconcelos, A.P.; De Araújo, D.A.; De Andrade Braga, V.; De Medeiros, I.A.; Alencar, J.L.; et al. Participation of the TRP channel in the cardiovascular effects induced by carvacrol in normotensive rat. Vasc. Pharmacol. 2015, 67, 48-58. [CrossRef] [PubMed]

54. Guo, X.; Cui, M.; Deng, M.; Liu, X.; Huang, X.; Zhang, X.; Luo, L. Molecular differentiation of five Cinnamomum camphora chemotypes using desorption atmospheric pressure chemical ionization mass spectrometry of raw leaves. Sci. Rep. 2017, 20, 46579. [CrossRef] [PubMed]

55. Silva-Filho, J.C.; Oliveira, N.N.; Arcanjo, D.D.; Quintans-Júnior, L.J.; Cavalcanti, S.C.; Santos, M.R.; Oliveira, R.C.; Oliveira, A.P. Investigation of mechanisms involved in (-)-borneol-induced vasorelaxant response on rat thoracic aorta. Basic Clin. Pharmacol. Toxicol. 2012, 110, 171-177. [CrossRef] [PubMed]

56. Bai, X.Y.; Zhang, P.; Yang, Q.; Liu, X.C.; Wang, J.; Tong, Y.L.; Xiong, S.J.; Liu, L.H.; Wang, L.; He, G.W. Suxiao jiuxin pill induces potent relaxation and inhibition on contraction in human artery and the mechanism. Evid. Based Complement. Altern. Med. 2014, 2014, 1-11. 
57. Wu, H.Y.; Tang, Y.; Gao, L.Y.; Sun, W.X.; Hua, Y.; Yang, S.B.; Zhang, Z.P.; Liao, G.Y.; Zhou, Q.G.; Luo, C.X.; et al. The synergetic effect of edaravone and borneol in the rat model of ischemic stroke. Eur. J. Pharmacol. 2014, 740, 522-531. [CrossRef] [PubMed]

58. Brocksom, T.J.; Brocksom, U.; De Sousa, D.P.; Frederico, D. Enantiopure cycloheptenones from (R)-(-)-Carvone: Intermediates for perhydroazulene terpenoids. Tetrahedron Asymmetry 2005, 16, 3628-3632. [CrossRef]

59. De Sousa, D.P.; De Farias Nóbrega, F.F.; De Almeida, R.N. Influence of the chirality of $(R)-(-)-$ and (S)-(+)-carvone in the central nervous system: A comparative study. Chirality 2007, 19, 264-268. [CrossRef] [PubMed]

60. Kundu, S.; Shabir, H.; Basir, S.F.; Khan, L.A. Inhibiti on of As (III) and Hg (II) caused aortic hypercontraction by eugenol, linalool and carvone. J. Smooth Muscle Res. 2014, 50, 93-102. [CrossRef] [PubMed]

61. De Sousa, D.P.; Mesquita, R.F.; De Araújo Ribeiro, L.A.; De Lima, J.T. Spasmolytic activity of carvone and limonene enantiomers. Nat. Prod. Commun. 2015, 10, 1893-1896. [PubMed]

62. Barceloux, D.G. Medical Toxicology of Natural Substances. Foods, Fungi, Medicinal Herbs, Plants and Venomous Animals; John Wiley \& Sons: Hoboken, NJ, USA, 2008.

63. Peixoto-Neves, D.; Leal-Cardoso, J.H.; Jaggar, J.H. Eugenol dilates rat cerebral arteries by inhibiting smooth muscle cell voltage-dependent calcium channels. J. Cardiovasc. Pharmacol. 2014, 64, 401-406. [CrossRef] [PubMed]

64. Gottlieb, O.R.; Magalhães, M.T. Occurrence of 1-nitro-2-phenylethane in Ocotea pretiosa and Aniba canelilla. J. Org. Chem. 1959, 24, 2070. [CrossRef]

65. Interaminense, L.F.; De Siqueira, R.J.; Xavier, F.E.; Duarte, G.P.; Magalhães, P.J.; Da Silva, J.K.; Maia, J.G.; Sousa, P.J.; Leal-Cardoso, J.H.; Lahlou, S. Cardiovascular effects of 1-nitro-2-phenylethane, the main constituent of the essential oil of Aniba canelilla, in spontaneously hypertensive rats. Fundam. Clin. Pharmacol. 2011, 25, 661-669. [CrossRef] [PubMed]

66. Murakami, A.; Kuki, W.; Takahashi, Y.; Yonei, H.; Nakamura, Y.; Ohto, Y.; Ohigashi, H.; Koshimizu, K. Auraptene, a citrus coumarin, inhibits 12-O-tetradecanoylphorbol-13-acetate-induced tumor promotion in ICR mouse skin, possibly through suppression of superoxide generation in leukocytes. Jpn. J. Cancer Res. 1997, 88, 443-452. [CrossRef] [PubMed]

67. Razavi, B.M.; Arasteh, E.; Imenshahidi, M.; Iranshahi, M. Antihypertensive effect of auraptene, a monoterpene coumarin from the genus Citrus, upon chronic administration. Iran. J. Basic Med. Sci. 2015, 18, 153-158. [PubMed]

68. Pereira, S.L.; Marques, A.M.; Sudo, R.T.; Kaplan, M.A.; Zapata-Sudo, G. Vasodilator activity of the essential oil from aerial parts of Pectis brevipedunculata and its main constituent citral in rat aorta. Molecules 2013, 18, 3072-3085. [CrossRef] [PubMed]

69. Melo, M.S.; Sena, L.C.; Barreto, F.J.; Bonjardim, L.R.; Almeida, J.R.; Lima, J.T.; De Sousa, D.P.; Quintans-Júnior, L.J. Antinociceptive effect of citronellal in mice. Pharm. Biol. 2010, 48, 411-416. [CrossRef] [PubMed]

70. Lima, N.G.; De Sousa, D.P.; Pimenta, F.C.; Alves, M.F.; De Souza, F.S.; Macedo, R.O.; Cardoso, R.B.; De Morais, L.C.; Melo Diniz, M.F.; De Almeida, R.N. Anxiolytic-like activity and GC-MS analysis of (R)-(+)-limonene fragrance, a natural compound found in foods and plants. Pharmacol. Biochem. Behav. 2013, 103, 450-454. [CrossRef] [PubMed]

71. Loizzo, M.R.; Tundis, R.; Bonesi, M.; Sanzo, G.D.; Verardi, A.; Lopresto, C.G.; Pugliese, A.; Menichini, F.; Balducchi, R.; Calabrò, V. Chemical profile and antioxidant Properties of extracts and essential oils from Citrus x limon (L.) Burm. cv. Femminello Comune. Chem. Biodivers. 2016, 13, 571-581. [CrossRef] [PubMed]

72. De Siqueira, R.J.; Rodrigues, K.M.; Da Silva, M.T.; Correia Junior, C.A.; Duarte, G.P.; Magalhães, P.J.; Dos Santos, A.A.; Maia, J.G.; Da Cunha, P.J.; Lahlou, S. Linalool-rich rosewood oil induces vago-vagal bradycardic and depressor reflex in rats. Phytother. Res. 2014, 28, 42-48. [CrossRef] [PubMed]

73. Kang, P.; Seol, G.H. Linalool elicits vasorelaxation of mouse aortae through activation of guanylyl cyclase and K (+) channels. J Pharm. Pharmacol. 2015, 67, 714-719. [CrossRef] [PubMed]

74. You, J.H.; Kang, P.; Min, S.S.; Seol, G.H. Bergamot essential oil differentially modulates intracellular $\mathrm{Ca}^{2+}$ levels in vascular endothelial and smooth muscle cells: A new finding seen with fura- 2 . J. Cardiovasc. Pharmacol. 2013, 61, 324-328. [CrossRef] [PubMed] 
75. Galeotti, N.; Di Cesare, M.L.; Mazzanti, G.; Bartolini, A.; Ghelardini, C. Menthol: A natural analgesic compound. Neurosci. Lett. 2002, 322, 145-148. [CrossRef]

76. Cheang, W.S.; Lam, M.Y.; Wong, W.T.; Tian, X.Y.; Lau, C.W.; Zhu, Z.; Yao, X.; Huang, Y. Menthol relaxes rat aortae, mesenteric and coronary arteries by inhibiting calcium influx. Eur. J. Pharmacol. 2013, 702, 79-84. [CrossRef] [PubMed]

77. Yeh, J.C.; Cindrova-Davies, T.; Belleri, M.; Morbidelli, L.; Miller, N.; Cho, C.W.C.; Chan, K.; Wang, Y.T.; Luo, G.A.; Ziche, M.; et al. The natural compound N-butylidenephthalide derived from the volatile oil of radix Angelica sinensis inhibits angiogenesis in vitro and in vivo. Angiogenesis 2011, 14, 187-197. [CrossRef] [PubMed]

78. Lahlou, S.; Magalhães, P.J.; Carneiro-Leão, R.F.; Leal-Cardoso, J.H. Involvement of nitric oxide in the mediation of the hypotensive action of the essential oil of Mentha $x$ villosa in normotensive conscious rats. Planta Med. 2002, 68, 694-699. [CrossRef] [PubMed]

79. Lahlou, S.; Carneiro-Leão, R.F.; Leal-Cardoso, J.H. Cardiovascular effects of the essential oil of Mentha $x$ villosa in DOCA-salt-hypertensive rats. Phytomedicine 2002, 9, 715-720. [CrossRef] [PubMed]

80. Sabino, C.K.; Ferreira-Filho, E.S.; Mendes, M.B.; Da Silva-Filho, J.C.; Ponte, M.P.; Moura, L.H.; Oliveira, E.C.; Quintans-Junior, L.J.; Dos Santos, M.R.; Oliveira, R.d.C.; et al. Cardiovascular effects induced by $\alpha$-terpineol in hypertensive rats. Flavour Fragr. J. 2013, 28, 333-339. [CrossRef]

81. Silva, D.F.; Araújo, I.G.; Albuquerque, J.G.; Porto, D.L.; Dias, K.L.; Cavalcante, K.V.; Veras, R.C.; Nunes, X.P.; Barbosa-Filho, J.M.; Araújo, D.A.; et al. Rotundifolone-induced relaxation is mediated by BK (Ca) channel activation and Ca (v) channel inactivation. Basic Clin. Pharmacol. Toxicol. 2011, 109, 465-475. [CrossRef] [PubMed]

82. Andrade, F.C.; Mota, M.M.; Barreto, A.S.; De Sousa, D.P.; Quintans-Junior, L.J.; Santos, M.R. Antihypertensive Therapeutic Potential of Citronellal. Lat. Am. J. Pharm. 2012, 31, 767-771.

83. Moon, H.K.; Kang, P.; Lee, H.S.; Min, S.S.; Seol, G.H. Effects of 1,8-cineole on hypertension induced by chronic exposure to nicotine in rats. J. Pharm. Pharmacol. 2014, 66, 688-693. [CrossRef] [PubMed]

(C) 2017 by the authors. Licensee MDPI, Basel, Switzerland. This article is an open access article distributed under the terms and conditions of the Creative Commons Attribution (CC BY) license (http:/ / creativecommons.org/licenses/by/4.0/). 